Широбоков Ю. кандидат психологічних наук, доцент, Харківський наиіональний університет Повітряних Сил імені Івана Кожедуба ORCID ID 0000-0001-7220-7340

\title{
ОСОБЛИВОСТІ ЗАСТОСУВАННЯ ФІЗИЧНОГО НАСИЛЬСТВА, ТОРТУР ТА ЖОРСТОКОГО ПОВОДЖЕННЯ ПО ВІДНОШЕННЮ ДО ВІЙСЬКОВОПОЛОНЕНИХ
}

\begin{abstract}
Стаття присвячена проблемі військового полону. У статті наводяться дані застосування по відношенню до військовополонених фізичного насильства, тортур та жорстокого поводження під час антитерористичної операиіі на сході України. Наведено опис обставин, процедур та способів потрапляння військовослужбовия у полон. Розглянуто процедури, щзо імітували діяльність органів дізнання, слідства чи судових органів на окупованих територіях, а саме: затримання, допити, засудження.

Ключові слова: військовослужбовиі; військовополонені; фізичне насильство; тортури; жорстоке поводження; полон; антитерористична операція.
\end{abstract}

Постановка проблеми.

Питання жорстокого поводження 3 полоненими завжди ставали центром уваги як закордонних так і вітчизняних вчених [1; 2 ; 3]. Особливої гостроти ця проблема набрала під час збройної агресії 3 боку Російської Федерації на Сході України. Великого значення набувають аспекти порушення міжнародних норм 3 прав людини в умовах гібридного протистояння на Донбасі. Як показує військова практика антитерористичної операції та операції Об'єднаних сил, втрати серед військовослужбовців фіксуються не тільки в бою, а й у полоні [4]. В цих умовах дуже важливим стає дослідження психологічних особливостей впливу, який здійснюється на військовослужбовців захоплених у полон на тимчасово окупованих територіях. Праць, спеціально присвячених вивченню особливостей застосування фізичного насильства, тортур та жорстокого поводження по відношенню до військовополонених, в сучасній психологічній літературі недостатньо [5], тому сама проблема залишається невирішеною: відсутні чіткі уявлення про способи впливу, 3 метою посилення фізичних та психологічних страждань військовополонених на непідконтрольних територіях, не розкрито зв'язок видів сучасного полону з процесом застосування тортур до військовополонених.

Таким чином, актуалізація питань застосування фізичного насильства, тортур та жорстокого поводження по відношенню до військовополонених зумовлює необхідність проведення самостійного дослідження особливостей цих процесів в умовах сучасного конфлікту. \section{публікацій.}

Проблема жорстокого поводження 3 полоненими має складності у дослідженні саме через те, що ті хто утримує полонених не готовий відповідати перед міжнародною спільнотою за скоєні військові злочини, як це відбувалося після II Світової війни. Саме тому більшість із тих, хто застосовує тортури та інші засоби морального та фізичного насилля унеможливлюе подальше документування власних злочинів, а саме вдається до страт полонених.

Усі сучасні дослідження жорстокого поводження з полоненими можна розділити на такі напрямки: по-перше, застосування фізичного насильства, тортур та жорстокого поводження по відношенню до військовополонених як засіб створення умов, перебування у яких призводитиме до фізичного знищення бранців [6]; по-друге, це напрямок пов'язаний 3 використанням полонених для медичних досліджень мілітаристською Японією [7] та нацистською Німеччиною [8]; по-третє, це напрямок дослідження психологічних особливостей допиту полоненого [9].

Також відомо, що під час ведення бойових дій в Афганістані душмани або вбивали їх після жорстоких катувань, або зберігали життя тим військовополоненим, хто виявляв бажання перейти в іслам та повернути зброю проти власної армії. [10]. 


\section{Питання психології}

Але досліджень пов'язаних з сучасними військовим конфліктом на Донбасі на сьогоднішній момент не достатньо [5], крім того більшість пов'язана саме 3 питаннями психологічної допомоги та реабілітації.

Таким чином, питання застосування фізичного насильства, тортур та жорстокого поводження по відношенню до військовополонених не $\epsilon$ достатньо вивченим та зумовлює необхідність проведення самостійного дослідження.

\section{Мета статті}

Визначити психологічні особливості застосування тортур до військовополонених у ході сучасного військового конфлікту

\section{Методи дослідження}

Під час дослідження використовувався наступні методи: контент-аналіз інтернетресурсів та інтерв'ювання військовослужбовців, які перебували у полоні.

Для проведення контент-аналізу був визначений перелік веб-ресурсів з визначеної тематики, який постійно збільшувався у ході проведення дослідження. Матеріали 3 цих веб-ресурсів підлягали регулярному моніторингу щодо наявності інформації про військовослужбовців, які перебували у полоні. Інформація, що належить до напрямку нашого наукового пошуку (фото, відео, скріншоти), копіювалася до певної бази даних для подальшого аналізу.

Інтерв'ю проводилося військовослужбовцями, які перебували у полоні та були звільнені 3 неволі на протязі 2014-2019 років. Інтерв'ю здійснювалися у форматі приватної бесіди з респондентами за їx письмової згоди. В ході інтерв'ю, звільнені в обстановці без емоційного слухання розповідали власну історію потрапляння у полон, утримання (експлуатація, допити, фізичний та моральний тиск) та звільнення. Крім того колишнім військовополоненим ставилися запитання для уточнення та деталізації фактів, що забезпечувало конфіденційність і недоторканність приватного життя колишнього бранця, а також допомагало уникнути неправдивих свідчень, перебільшення та домислення; все це сприяло досягненню належного рівня вірогідності даних, підтверджених заявами респондентів.

У ході інтерв'ю кожному респонденту пропонувалося викласти власну історію 3 наступних аспектів: обставини захоплення; опис локацій та умов утримання; допити та примусова експлуатація в місцях утримання; інформація про тих, хто залишився у полоні; інформація про застосування фізичного насильства, тортур та жорстокого поводження, отримані травми, ушкодження та хвороби; інформація про наявність на окупованих територіях військовослужбовців Російської Федерації; обставини звільнення; застосування моральних та фізичних засобів впливу; додаткова інформація.

В межах дослідження оцінка надійності свідка грунтувалась на визначенні ступеня ризику надання недостовірної інформації 3 наступною прогресивною шкалою:

- 30\% i нижче - високонадійні свідчення;

- від 30\% до 50\% - достатньо надійні свідчення;

- від 50\% до 70\% - свідчення під сумнівом;

- вище 70\% - ненадійні свідчення.

Для визначення ступеня ризику надання недостовірної інформації використовувались індикатори:

1)наявність обгрунтованих підстав вважати особу завербованою службами так званих “ЛНР”, “ДНР” чи Російської Федерації;

2)складний психологічний стан колишнього військовополоненого, наявність негативного висновку психолога чи психіатра щодо адекватності стану особи;

3)наявність підозр щодо факторів які спотворюють інформацію, зокрема: бажання спотворити інформацію через вчинення злочину, матеріальні інтереси, психологічні потреби.

Для уникнення повторного травмування військовослужбовців, які перебували у полоні, респондентів детально інформували про цілі та завдання інтерв'ю, отримували письмову згоду на його проведення. Окремим моментом було отримання згоди респондента на обробку його персональних даних.

Виклад основного матеріалу.

Для проведення дослідження була обрана група респондентів, які на протязі 2014-2019 року були звільнені з полону (усього 240 осіб). Загальна характеристика контингенту досліджуваних наведена у табл. 1. 
Загальна характеристика контингенту досліджуваних

\begin{tabular}{|c|c|c|c|c|c|c|c|c|c|}
\hline \multirow{3}{*}{ № } & \multirow{3}{*}{\multicolumn{2}{|c|}{ Характеристики респондентів }} & \multirow{2}{*}{\multicolumn{7}{|c|}{ Звільнені по роках\% }} \\
\hline & & & & & & & & & \\
\hline & & & 2014 & 2015 & 2016 & 2017 & 2018 & 2019 & Разом \\
\hline \multirow{3}{*}{1} & \multirow{3}{*}{ Статус } & Офіцери & 1,7 & 3,8 & 1,3 & 2,5 & 0 & 3,3 & 12,5 \\
\hline & & Сержанти & 9,6 & 5,8 & 1,7 & 3,8 & 0 & 3,8 & 24,6 \\
\hline & & Солдати & 39,6 & 8,3 & 1,7 & 5,8 & 0,4 & 4,6 & 60,4 \\
\hline \multirow{2}{*}{2} & \multirow{2}{*}{ Стать } & Чоловіки & 50,8 & 17,9 & 4,6 & 11,7 & 0 & 11,7 & 96,7 \\
\hline & & Жінки & 1,7 & 0,8 & 0 & 0,4 & 0,4 & 0 & 3,3 \\
\hline & \multirow{4}{*}{$\begin{array}{l}\text { Вік } \\
\text { (років) }\end{array}$} & До 25 & 26,7 & 4,6 & 0 & 0,4 & 0 & 4,6 & 36,7 \\
\hline & & $26-35$ & 15 & 7,5 & 2,5 & 8,8 & 0,4 & 4,6 & 38,8 \\
\hline 3 & & $36-45$ & 7,9 & 5,8 & 2,1 & 9,6 & 0 & 1,3 & 26,7 \\
\hline & & 46 і більше & 1,3 & 0,8 & 0 & 1,7 & 0 & 1,3 & 4,6 \\
\hline \multirow{4}{*}{4} & \multirow{4}{*}{$\begin{array}{l}\text { Термін утримання у } \\
\text { полоні }\end{array}$} & До 1 місяця & 6,7 & 5 & 0 & 0 & 0 & 0 & 11,7 \\
\hline & & До 1 року & 44,2 & 13,8 & 3,8 & 8,8 & 0,4 & 11,7 & 82,5 \\
\hline & & 1-2 роки & 0 & 0 & 0,8 & 1,3 & 0 & 0 & 2,1 \\
\hline & & 3-4 роки & 0 & 0 & 0 & 2,1 & 0 & 0 & 2,1 \\
\hline \multirow{3}{*}{5} & \multirow{3}{*}{ Підрозділ } & ЗС України & 35,4 & 9,6 & 4,6 & 7,5 & 0 & 11,7 & 69,2 \\
\hline & & МВС України & 13,8 & 7,9 & 0 & 1,7 & 0,4 & 0 & 23,8 \\
\hline & & Добробати & 1,7 & 1,3 & 0 & 2,9 & 0 & 0 & 5,4 \\
\hline
\end{tabular}

3 табл. 1. видно що, у дослідженні приймали участь респонденти 3 різною приналежністю до військової служби, життєвим та професійним досвідом, різної статі та віку, крім того групи досліджуваних також мали відмінності у термінах перебування в полоні. Такі відмінності впливали на якість інтерв'ювання респондентів, так жінки, які повернулися 3 полону демонстрували контактність та готовність до участі у дослідженнях, на відміну від чоловіків. Крім того, вікові відмінності так само впливали на контактність респондентів, так вікові групи до 25 років та ті, кому понад 46 років так само більш охоче брали участь у процесі опитування, а категорії респондентів від 26 до 45 років ставилися до інтерв'ю 3 недовірою.

Найбільш сильний негативний вплив на якість отриманої інформації мали наслідки довготривалого перебування у примусовій ізоляції, так 2,1 \% респондентів, які перебували у неволі більше 3-х років

Таким чином розподіл респондентів за соціально-демографіцчними

характеристиками, досвідом та приналежністю дозволяє стверджувати, що отримані результати відображають загальну специфіку контингенту повернених після полону, та дозволяють виявити, що на якість інтерв'ю впливають більше всього гендерні та вікові відмінності респондентів, а також терміни їх перебування у полоні.
Крім того, близько 69,2\% осіб потрапили у полон під час безпосереднього виконання завдань за призначенням, в тому числі у зв'язку із потраплянням під обстріли та у засідки ворога. В приблизно 30,8\% військовослужбовців потрапили у полон 3 пораненнями різного ступеню тяжкості. За свідченнями військовослужбовців, які потрапляли у полон 3 пораненнями, медична допомога їм надавалась, у обсязі, необхідному для врятування життя: робились перев'язки, у найскладніших випадках - проводились операції у медичних закладах. Однак, подальший медичний супровід не здійснювався, зокрема, зняття швів після операцій проводили полонені один одному.

За свідченнями військовослужбовців, які мали під час потрапляння у полон поранення (44,2\%), наявність поранень та проведені складні операції не позбавляли їх від тортур та жорстокого поводження 3 ними, а також застосування щодо них фізичного чи психологічного насильства. Затримання військовослужбовців відбувалось, в основному в умовах бойових дій. Під час затримання до поранених військовослужбовців у багатьох випадках застосовувалось фізичне насильство без наявних для того підстав, зокрема, щодо обеззброєних, зв'язаних та навіть непритомних осіб.

У 96,7 \% проаналізованих випадків допити супроводжуються застосуванням 


\section{Питання психології}

тортур, фізичного чи психологічного насильства, погрозами чи іншими засобами тиску. Як показала більшість респондентів в основному, щодо військовополонених допити проводились особами, які закривали обличчя та не називали власних імен або позивних. Інколи військовополонені могли дізнатися чи встановити особу, яка проводила допити, зокрема, якщо ця персона займала високу посаду чи була відомою, а також встановити підрозділ незаконного збройного формування, у якому проводився допит. Зокрема, декілька осіб (2,5\%) стали жертвами тортур, що вчинялись безпосередньо ватажком так званої "ДНР" Захарченко О.В., який імітував розстріл цих осіб.

Допити проводили працівники так званих “МГБ ЛНР”, “МГБ ДНР”, особи, яких неможливо було встановити через закриття очей військовополоненим, або закриття облич особам, які допитували. Однак, допити із застосуванням тортур, фізичного чи психологічного насильства, погрозами чи іншими засобами тиску проводились 3 усіма полоненими як частина процедури слідства, в приміщеннях “органів влади ЛНР” чи “органів влади ДНР”. Наявна інформація дає підстави вважати, що застосування вказаних форм допитів санкціонована російсько-терористичною владою цих псевдореспублік.

Військовослужбовці, які перебували у полоні, зазначають декілька місць їх утримання. 3 перших годин незаконного утримання полонених направляють до приміщень підрозділів, які практикують застосування різних видів тортур, фізичного чи психологічного насильства чи інших засобів тиску. Період тримання в таких приміщеннях коливається від кількох днів до кількох місяців.

За свідченнями $82,5 \%$ респондентів приміщень, в яких щодо затриманих осіб застосовуються тортури, фізичне та психологічне насильство, відносяться:

1.Підвал приміщення "МГБ ЛНР", адреса: місто Луганськ, вулиця Радянська, будинок 81.

2.Підвал приміщення “МГБ ДНР”, адреса: місто Донецьк, бульвар Шевченко, будинок 26.
3.Приміщення колишнього Заводу теплоізоляційних матеріалів «Ізоляція», адреса: місто Донець, Буденовсткий район, вулиця Свєтлого путі, будинок 3.

4.Підвал колишнього приміщення Управління Служби безпеки України в Донецькій області: місто Донецьк, вулиця Щорса, будинок 62.

5.Підвал будівлі, що відноситься до так званого «Міністерства внутрішніх справ Луганської Народної Республіки», адреса: місто Луганськ, вулиця Гастелло, будинок 40a.

Серед вказаних місць особливо небезпечним, 3 точки зору застосування тортур, на думку $60,4 \%$ опитаних, вважається так звана "Ізоляція" приміщення колишнього Заводу теплоізоляційних матеріалів «Ізоляція», адреса: місто Донець, Буденовсткий район, вулиця Свєтлого путі, будинок 3.

Із безпосередніх свідчень полоненого:

“...nотім, коли з ще одного місия почали звозити, це був засекречений об'єкт, про нього ніхто не знав, ну там катівня там була, де людей “урабативалі”, деякі від туди взагалі не поверталися, їх там вбивали, замордовували ... ми дізналися про цุю ізолящію..."

Про утримання полоненни в зазначених місцях окупаційні органи влади не повідомляють, зв'язок з зовнішім світом заборонено.

Із безпосередніх свідчень полоненого:

“... Ну я тоді не знав, щзо ие завод ізоляиії, щзо ие база МГБ, де вони тримають ось, незаконно. Незаконно там взагалі, иих людей. I навіть родичі не знають де вони. Вони навіть не дають інформачії, де вони, щзо вони у них знаходяться..."

У подальшому, за свідченнями 60,4\% респондентів, полонених переводили до псевдо-офіційних місць утримання.

Крім того, 96,7\% відсотків опитаних, які повернулись 3 полону свідчать про застосування до них різних форм фізичного насильства, тортур, жорстокого поводження. $1,3 \%$, щодо яких заходи фізичного спливу не застовувались, свідчать про різні форми психологічного тиску, зокрема, погрози щодо рідних. 


\section{Питання психології}

Найбільш розповсюдженим засобом насильницького впливу на думку 100\% є побиття: руками, ногами, гумовими палками, предметами меблів по різним частинам тіла. У побитті могли брати участь як одна так і декілька осіб. Побиття, було характернее для військових підрозділів, які утримували полонених, воно могло тривати до 12 годин, при чому особи, які приймали участь у побитті, змінювались. Крім того, до полонених також застосовувались i позбавлення їжі та сну. Наявність поранень, встановлених за результатом огляду лікаря струсів мозку не ставало підставою для припинення допитів із застосуванням фізичного насильства. Місцями здійснення побиття були всі місця тримання полонених, до часу потрапляння до псевдоофіційних установ утримання: слідчі ізолятори, колонії.

3 безпосередніх свідчень полоненого:

“ ... під час допиту я втратив свідомість, мене привели до тями, знову стукнули по голові $i$ я знов втратив свідомість. Я прокинувся в іншому кабінеті, поряд була лікар (особа в білому халаті) яка сказала, щуо в мене струс і мене не можна допитувати. Вона зробила мені укол ... Після иього мене знов повернули до кабінету де проводили допит і почали бити по ребрам і ниркам..."

3 безпосередніх свідчень полоненого:

“... я прокинувся зв'язаний скотчем біля машини, подій майже не пам'ятаю. Медичної допомоги не надали. Нас почали бити великою толпою били руками, ногами, зброєю, по всьому тілу. Мені зломали ніс, по всьому тілу були гематоми, зломали зуби та ребра. Після того підвішували за руки на ланщюгах..."

За свідченнями $15 \%$ респондентів емітація розстрілу, як вид впливу застосовувався як до цивільних осіб так і до військовослужбовців. Як визначають ті, що пережили подібний вплив, такі заходи, сильно і негативно впливають на психічний стан полоненного, особливо коли таких емітацій проводилося декілька.

Із безпосередніх свідчень полоненого:

“... Вночі мене вивели з камери, наділи мішок на голову, посадили до автомобіля... Мене вивезли за місто, там була вирита яма, вивели з машини, збили з ніг, заставили молитися, О.В.Захарченко спитав про останнє бажання, я сказав щзоб повернули тіло додому. До потилищі приставили зброю, я почув клачання курка. Почали бити, підняли. Знов збили з ніг, поставили на коліна, стали сзаду та вистрелили з АПС над правим вухом..."

58,3\% осіб, які перебували у полоні свідчать про застосування під час допитів в якості тортур електричного струму, зокрема - приєднання дротів, зєднаних 3 віськовопольовим телефонним апаратом (так званий “тапік”). Дроти від “тапіку” могли приєднуватися до різних частин тіла: нижніх та верхніх кінцівок, пальців рук i ніг, геніталій. Для посилення болю дроти могли приєднати до наручників, поклавши на голову мокру ганчірку. У випадку значного реагування на цей вид тортур, електричний струм могли застосовувати по декілька десятків разів, в тому числі, за відсутності потреби дізнатися будь-яку інформацію. Такий тип тортур був більше характерний для найманців. При чьому, “Тапік” застсовували як до незаконно жінок, так і до чоловіків.

3 безпосередніх свідчень полоненого:

“ ... Через декілька днів мого перебування в полоні під час допитів почали застосовувати дроти з током, приєднавщи ïх до ТА - 57 (військово-польовий телефонний апарат, або “Тапік”). Мене виводили з камери, одягали мішок на голову та везли у невідомому напрямку. Мене привозили до невідомого приміщення, садили на стілечь, прикручували дроти до наручників, клали мокру ганчірку на голову та били током до втрати свідомості. Такі тортури вчинялись щодо мене приблизно 40 днів. Перші 10 разів мені задавали питання, потім нічого не питали, били током без наміру дізнатися інформацію чи примусити щоссь робити..."

30,4\% респондентів засвідчили про застосовування до них тортур у вигляді придушення із використанням пакету. Насильницький вплив через придушення здійснювався до моменту, поки полонений не втрачав свідомість. Зазначене повторювалося декілька разів підряд.

3 безпосередніх свідчень полоненого: 


\section{Питання психології}

“ ... били куди попало. Ну в основному по спині. Ну й по голові також, і по началу, ну коли нас оце били у мене пакет був на голові. Ну понадівали пакети, скотчем. То били, то перекривали повітря, ну щэоб дихати не міг. Думав, щзо удушать..."

За свідченням $75,4 \%$ опитаних крім зазначених вище видів насильства, підрозділами найманців, до полонених застосовувались інші способи впливу, 3 метою посилення фізичних та психологічних страждань.

До таких заходів відносяться:

- різання тіла та погрози щодо цього

3 безпосередніх свідчень полоненого:

“... мені погрожсували, щчо відріжуть пальціi на лівій руці. Зафіксували руку, підклали під руку пакет, взяли військовий тактичний ніж. Розмахуючи ножем, мені зрізали нігтьову пластину з часткою пальия, почала бігти кров...”

- пиляння зубів напильником, виривання зубів плоскогубцями;

- підвішування за руки на ланцюг;

- встромляння дротів у вуха для пробиття барабанної перетинки, гасіння цигарок у вухах;

- заборона відвідування туалету для справляння природних потреб;

- залишення у камері самого без світла на кілька тижнів;

- ненадання їжі, води;

- інші тортури.

Деякі респонденти (6,7\%) визначили піддавання привселюдному приниженню, як досить дієвий засіб насильницьких дій. Зокрема, військовополонених примусили вибачатися за дії ЗС України, які приписувались їм пропагандистськими джерелами російсько-терористичних військ.

3 безпосередніх свідчень полоненого:

“... Нас поставили на кригу, охорониі стояли поряд з автоматами, націленими на нас. До нас підійшов чоловік, ... Він оголосив, щзо ми двоє заӥхали на територію ДНР на танках. Частина изивільних людей, щзо там перебували, були щооо нас вороже налаштовані: почали лаятися, хотіли нас побити... нам повідомили, щзо ми маємо просити у всіх присутніх пробачення інакше нас розстріляють.
Нас збили з ніг, вдаривши ззаду під колінами прикладами автоматів, ми впали на коліна. Нас змусили просити пробачення..."

Під час проведення опитування були встановлені факти згвалтувань як жінок $(1,7 \%)$, так і окремих чоловіків (2,9\%). Особи, які перенесли такий важкий вплив, особливо чоловіки, висловлювали небажання говорити про такі факти, але відмічали, що такий вчинок дуже сильно травмує психіку полоненого. У більшості випадків до таких дій вдавалися представники банд формувань, 3 метою схиляння полоненого та його рідних до виплати "викупу".

Однією з основних цілей застосування насильницького впливу на військовополонених було примушення їх до участі у зйомці постановочних відео за попередньо підготованим сценарієм. Близько 82,5\% колишніх полонених, свідчать, що були піддані примусовому фільмуванню. Однак не всі відзняті сюжети вийшли в ефір та або були завантажені до мережі Інтернет. Деякі відео знімалися представниками банд формувань лише 3 метою отримання наживи. Примусове фільмування відбувалось через примушення до зачитування підготовлених текстів.

Зазначені відео мали чітко визначені теми та чітко спрямовані цілі інформаційного впливу на населення, як України так i Російської Федерації. Основними темами “зізнань" військовослужбовців були наступні:

1) наклеп та очорнення Збройних Сил України, добровольчих підрозділів (розповіді про вживання ними алкоголю та наркотиків, нестачу військової техніки та особового складу);

2) свідчення перехід на бік незаконних збройних формувань через нестерпні умови під час служіння в Збройних Силах України

Таким чином, у кінцевому результаті усіх військовополонених примушують до експлуатації, а для прискорення процесу застосовують фізичне насильство, тортури та жорстоке поводження.

Висновки та перспективи подальших досліджень. 


\section{Питання психології}

1. Застосування фізичного насильства, тортур та жорстокого поводження по відношенню до військовополонених в умовах сучасного конфлікту має чітко виражену мету - примушення бранця до співпраці (надання свідчень, участь у фільмуванні та примусове самозвинувачення), що створює створює свої унікальні умови для схиляння полоненого до колаборації.

2. В умовах гібридної війни, захоплення військовослужбовців у полон має психологічні особливості у залежності від виду підрозділу, який їх утримує та характеризується різною метою, для військових підрозділів це в основному необхідність припинення спротиву ворога, а також демонстрація сили і майстерності та залякування противника Для них характерним було побиття полонених та позбавлення їх сну та їжі, під час допитів, 3 метою запобігання втечі та схиляння до співробітництва. Професійні найманці мали на меті залякування противника та демонстрацію сили і майстерності. Допит професійними найманцями характеризувався жорстоким катуванням, застосуванням під час допитів в якості тортур електричного струму, придушення із використанням поліетиленового пакету та іншими способами впливу, а також насиллям та вбивствами військовополонених. Для бандформувань характерними були обмін на своїх, отримання викупу. Характерною особливістю допиту, який проводився представниками банд формувань були знущання над полоненими з метою наживи.

3. Перспективним напрямком подальшого наукового пошуку, на наш погляд є дослідження методик діагностики та психологічної роботи 3 травмою для кожного конкретного випадку (згвалтування, ампутації, кастрації та ін.).

\section{Список використаних джерел}

1. Калкутіна Н. В. Міжнародно-правове регулювання військового полону та правовий статус іноземних військовополонених в СРСР на початку XX ст. Науковий вісник Миколаӥвського національного університету імені В.О. Сухомлинського. Серія : Історичні науки. Миколаїв, 2014. Вип. 3.37. C. $63-67$.

2. Nachtigal R. Kriegsgefangenschaft an der Ostfront 1914-1918. Literaturberichtzu einem neuen Forschungsfeld. Frankfurt am Main, 2005. 162 p.

3. Moritz V. Gefangenschaft und Revolution: Deutschösterreichische Kriegsgefangene und Internationalisten in Russland 1914 bis 1920. Viena: University of Vienna, 1995. P. 28 - 42.

4. Сна А. І. Актуальність і організаційні засади медико-психологічної реабілітації учасників антитерористичної операції. Науковий журнал МОЗ України. Київ, 2014. № 1. С. 5-16.

5. Тi, що пережили пекло: свідчення жертв про місця незаконних ув'язнень на Донбасі / Коаліція громадських організацій та ініціатив «Справедливість заради миру на Донбасі». Бєлоусов Ю.Л., Кориневич А.О., Мартиненко О.А., Матвійчук О.В., Павліченко О.М., Роменський Я.В., Швець С.П.; за редакцією авторів. Київ, 2015. 84 с.

6. Франкл В. Сказать жизни «Да!»: Психолог в концлагере Пер. с нем. 2-е изд. Москва, 2011. 239 с.

7. Акияма Х. Особый отряд 731 Akiyama H., Tokushu Butai Nanasanichi. Tokyo: San'ichi shobo, 1956 Пер. с яп. М. А. Гусева, В. А. Зломанова, А. Г. Рябкина, Н. Н. Тулинова. Москва, 1958. 152 с.

8. George J. Annas Edward R. Utley Professor of Health Law, Medicine Michael A. Grodin Associate. Oxford, 1992. $400 \mathrm{p}$.

9. Сыропятов О.Г. Психология допроса военнопленных. Киев, 2013. 156 с.

10. Маков В. О судьбах пропавших в Афганистане. livejournal. 29 марта 2013. Режим доступу: http://yarodom.livejournal.com/688455.html.

\section{References}

1. Kalkutina, N. (2014). Mizhnarodno-pravove rehuliuvannia viiskovoho polonu ta pravovyi status inozemnykh viiskovopolonenykh v USSR na pochatku XX st. [International Legal Regulation of Captivity and Legal Status of Foreign Prisoners in the USSR in the Early Twentieth Century.]. Naukovyi visnyk Mykolaivskoho natsionalnoho universytetu imeni V.O. Sukhomlynskoho. Seriia : Istorychni nauky. Mykolaiv, 2014. Vyp. 3.37. S. 63 - 67 (in Ukrainian).

2. Nachtigal, R. (2005). Kriegsgefangenschaft an der Ostfront 1914-1918. Literaturberichtzu einem neuen Forschungsfeld. Frankfurt am Main. 162 p. 


\section{Питання психології}

3. Moritz, V. (1995). Gefangenschaft und Revolution: Deutschösterreichische Kriegsgefangene und Internationalisten in Russland 1914 bis 1920. Viena: University of Vienna. P. $28-42$.

4. Yena A. (2014). Aktualnist i orhanizatsiini zasady medyko-psykholohichnoi reabilitatsii uchasnykiv antyterorystychnoi operatsii. [Topicality and organizational principles of medical and psychological rehabilitation of participants of anti-terrorist operation]. Naukovyi zhurnal MOZ Ukrainy. Kyiv. № 1. S. 5-16 (in Ukrainian).

5. Bielousov, Yu., Korynevych, A., Martynenko, O., Matviichuk, O., Pavlichenko, O., Romenskyi, Ya., Shvets, S. (2015).Ti, shcho perezhyly peklo: svidchennia zhertv pro mistsia nezakonnykh uviaznen na Donbasi [The survivors of hell: testimonies of victims of illegal detention in Donbass]. Koalitsiia hromadskykh orhanizatsii ta initsiatyv «Spravedlyvist zarady myru na Donbasi». Kyiv. 84 s (in Ukrainian).

6. Frankl, V. (2011). Skazat zhyzny «Da!»: Psykholoh v kontslahere. [Saying yes to life: A psychologist in a concentration camp]. Per. s nem. 2-e yzd. Moskva. 239 s (in Ukrainian).

7. Akyiama, Kh. (1956). Osobyi otriad 731. [Special Detachment 731]. Akiyama H., Tokushu Butai Nanasanichi. Tokyo: San'ichi shobo. Per. s yap. M. A. Huseva, V. A. Zlomanova, A. H. Riabkyna, N. N. Tulynova. Moskva. $152 \mathrm{~s}$ (in Ukrainian).

8. George, J. (1992). Annas Edward R. Utley Professor of Health Law, Medicine Michael A. Grodin Associate. Oxford. $400 \mathrm{p}$.

9. Syropiatov, O. (2013). Psykholohyia doprosa voennoplennykh. [Psychology of interrogation of prisoners of war].Kyev, $156 \mathrm{~s}$ (in Ukrainian).

10. Makov, V. (2013). O sudbakh propavshykh $\mathrm{v}$ Afhanystane. [The fates of the missing in Afghanistan]. livejournal. 29 marta 2013. Rezhym dostupu: http://yarodom.livejournal.com/688455.html (in Ukrainian).

\section{Резюме \\ Широбоков Ю. кандидат психологических наук, дочент, Харьковский начиональный университет Воздушных Сил имени Ивана Кожедуба \\ ОСОБЕННОСТИ ПРИМЕНЕНИЯ ФИЗИЧЕСКОГО НАСИЛИЯ, ПЫТОК И ЖЕСТОКОГО ОБРАЩЕНИЯ ПО ОТНОШЕНИЮ К ВОЕННОПЛЕННЫМ}

Статья посвящена проблеме военного плена. В статье приводятся данные применения по отнотению к военнопленным физического насилия, пьток и жестокого обрамения во время антитеррористической операции на востоке Украины. Приведено описание обстоятельств, процедур и способов попадания военнослужащего в плен. Рассмотрены прочедуры, имитирования деятельности органов дознания, следствия или судебных органов на оккупированных территориях, а именно: задержание, допросы, осуждение.

Ключевые слова: военнослужащие; военнопленные; физическое насилие; пытки; жестокое обращение; плен; антитеррористическая операчия.

\section{Summary \\ Shyrobokov Yu. PhD in Psychology, Kharkiv National \\ University of Air Force named after Ivan Kozhedub \\ FEATURES OF THE USE OF PHYSICAL VIOLENCE, TORTURE AND ILL-TREATMENT TO PRISONERS OF WAR}

Introduction. The military conflict which is being carried out in the east of Ukraine, brings forward new requirements to various aspects of the military's life activity. Aspects of the troops capture by the opposing party become much more important. The questions of survival of the military in captivity in the course of contacts with people who escort soldiers after the capture, guards and local population when traveling on enemy territory in case of escape turn out to be of current interest. The vast majority of prisoners faced the conditions that they could not even imagine in their life environment before war (another level of living, restrictions, humiliation, bullying, violence, beatings, torture, etc.), which encourage them to strive to achieve a common goal - to survive. As a result of non-stop interrogations, constant beatings and abuse soldiers in captivity have changes in the nature of the physiological and psychological activity.

In our opinion, the question of the application of torture to prisoners of war is very relevant, especially their impact on the psyche of soldiers and psychological consequences of staying in these conditions. conflict.

Purpose: to identify the psychological features of torture against prisoners of war in the current military

Methods: content analysis of online resources and interviews. 


\section{Питання психології}

Originality. The article presents data on the use of physical violence, torture and ill-treatment in relation to prisoners of war during the anti-terrorist operation in the East of Ukraine. The description of the circumstances, procedures and methods of getting a soldier into captivity is provided. The procedures that imitated the activities of the bodies of inquiry, investigation or judicial bodies in the occupied territories, namely, detention, interrogation, conviction, are considered. The article reviews the places of illegal detention of prisoners of war and identifies the possibility of using various types of torture, physical or psychological violence or other means of pressure in these conditions. The article analyzes the most common means of violent influence (beatings, simulated shooting, electric current, strangulation, public humiliation, etc.). The most common means of violence is beating: with hands, feet, rubber sticks, pieces of furniture, on various parts of the body. One person as well as and several people participated in the procedure of beating the prisoner. The data on application during interrogations an electric current as a torture, by means of the military telephone device is presented. The article presents data on the use of torture in the form of suppression using a plastic bag. Violent influence due to suppression was carried out until the person lost consciousness. This was repeated several times in a row. In addition to the above types of violence, other methods of influence were applied to the military servants who were in captivity in order to increase physical and psychological suffering (public humiliation, rape, threats against close people and family members, etc.). The article determines that one of the main purposes of the use of violent influence on persons who were in illegal isolation was to force them to participate in the shooting of staged videos according to a pre-prepared scenario.

Conclusion.

1. Being a soldier in the psychological environment of "cultural trauma" leads to deformation of the personality of a prisoner, in some cases it can result in personal growth, in others it leads to regressive behaviors and degradation that could be considered as boundaries of this psychological environment.

2. In a hybrid war capturing of soldiers has psychological characteristics depending on the type of unit that they are held captive at and has different purposes, for military units it is mainly the need to cease resistance of the enemy, and to demonstrate the strength, skill and intimidate the enemy, beatings of prisoners and depriving them of sleep and food was common among them, interrogations were carried out to prevent escape and induce cooperation. Professional mercenaries intend to intimidate the enemy and demonstrate the strength and skill, interrogations of professional mercenaries were characterized by brutal torture, violence and murders of prisoners of war. Exchanges and buyouts were typical for gangs. The characteristic feature of interrogation, conducted by the gang units, was abuse of prisoners for profit.

3. In our opinion, the perspective direction of further scientific research is the study of methods of diagnosis and psychological work with trauma for each particular case (rape, amputation, castration, etc.).

Key words: servicemen; prisoners of war, physical violence, torture, ill-treatment, anti-terrorist operation. 